\title{
HSD17B4 Gene
}

National Cancer Institute

\section{Source}

National Cancer Institute. HSD17B4 Gene. NCI Thesaurus. Code C114364.

This gene is involved in fatty acid oxidation. 